\title{
First molecular detection of Mycoplasma ovis (Hemotropic mycoplasmas) from Sheep in Brazil
}

\author{
Primeira detecção molecular de Mycoplasma ovis (Micoplasmas Hemotrópicos) em Ovinos no Brasil \\ Ugo Araújo Souza $^{1}$ (D); Karina Oberrather ${ }^{1}$ (D); Renata Fagundes-Moreira ${ }^{1}$ (D); Bruno Albuquerque de Almeida ${ }^{1}$; \\ Stella de Faria Valle ${ }^{1}$ (1); Aline Girotto-Soares ${ }^{2}$ (i); João Fábio Soares ${ }^{1 *}$ (D)
}

${ }^{1}$ Departamento de Patologia Veterinária, Universidade Federal do Rio Grande do Sul - UFRGS, Porto Alegre, RS, Brasil

${ }^{2}$ Instituto de Pesquisas Veterinárias Desiderio Finamor - IPVDF, Eldorado do Sul, RS, Brasil

Received January 18, 2019

Accepted March 13, 2019

\begin{abstract}
Mycoplasma ovis is an emerging zoonotic pathogen with a worldwide distribution and can cause mild to severe hemolytic anemia, icterus, and poor weight gain in animals. Although $M$. ovis has been described in small ruminants worldwide, data on M. ovis in sheep in Brazil is unknown. The objective of the present study was to present the first report of hemotropic mycoplasma (HM) in sheep from Brazil. We evaluated factors associated with this infection, such age group, tick presence, and anemia. Blood samples were collected from 33 sheep from a farm in southern Brazil and screened for hemoplasmas using PCR. Out of 33 samples, 26 (78.8\%) tested positive for $M$. ovis. The sequencing of positive samples showed $100 \%$ identity with multiple $M$. ovis $16 \mathrm{~S} \mathrm{rDNA}$ sequences. No association was observed between the presence of $M$. ovis and the FAMACHA ${ }^{\odot}$ score $(\mathrm{p}=0.620)$. Rhipicephalus (Boophilus) microplus $(15 / 33,45.4 \%)$ was the tick species found on the animals. No significant association between $M$. ovis infection and presence of ticks $(\mathrm{p}=0.4134)$ and age group $(\mathrm{p}=0.4221)$ was observed. This is the first report of $M$. ovis infection in sheep from Brazil and only the second report of this pathogen in sheep in Latin America.
\end{abstract}

Keywords: Hemoplasmas, small ruminants, 16S rRNA gene, Rio Grande do Sul.

\section{Resumo}

Mycoplasma ovis é um patógeno zoonótico emergente com distribuição mundial e pode causar anemia hemolítica de leve a grave, icterícia e baixo ganho de peso em animais. Embora $M$. ovis tenha sido descrito em pequenos ruminantes em todo o mundo, os dados sobre M. ovis em ovinos no Brasil sáo desconhecidos. O objetivo deste estudo foi apresentar o primeiro relato de micoplasmas hemotrópicos em ovinos no Brasil. Avaliamos os fatores associados a essa infecção, como faixa etária, presença de carrapatos e anemia. Amostras de sangue foram coletadas de 33 ovelhas de uma fazenda no sul do Brasil e testadas para hemoplasmas usando a PCR. Das 33 amostras, 26 (78,8\%) apresentaram resultado positivo. O sequenciamento das amostras positivas mostrou $100 \%$ de identidade com múltiplas sequências de $M$. ovis $16 \mathrm{~S}$ rDNA. Não foi observada associação entre a presença de $M$. ovis e o escore FAMACHA ${ }^{\circ}(\mathrm{p}=0,620)$. Rhipicephalus (Boophilus) microplus $(15 / 33,45,4 \%)$ foi a espécie de carrapato encontrada nos animais. Não houve associaçáo significativa entre infecção por $M$. ovis e presença de carrapatos ( $\mathrm{p}=0,4134)$ e faixa etária $(\mathrm{p}=0,4221)$. Este é o primeiro relato de infecção por M. ovis em ovinos no Brasil e o segundo relato deste patógeno em ovinos na América Latina.

Palavras-chave: Hemoplasmas, pequenos ruminantes, gene $16 \mathrm{~S}$ rRNA, Rio Grande do Sul.

\section{Introduction}

Hemotrophic mycoplasmas (HM; formerly classified as Eperytbrozoon \& Haemobartonella) are small pleomorphic, uncultivable bacteria, which attach themselves to the surface of erythrocytes. They can cause hemolytic anemia in a wide variety of mammals

*Corresponding author: João Fábio Soares. Departamento de Patologia Veterinária, Universidade Federal do Rio Grande do Sul - UFRGS, Av. Bento Gonçalves, 9090, CP 15094, CEP 91540-000, Porto Alegre, RS, Brasil. e-mail: jfsvet@gmail.com including pigs, cattle, cats, dogs, deer, and humans (MESSICK, 2004; HOELZLE, 2008; GROEBEL et al., 2009; ZHOU et al., 2009; GRAZZIOTIN et al., 2011a; GIROTTO et al., 2012; MACHADO et al., 2017; SYKES et al., 2010; MAGGI et al., 2013).

The description of HM in small ruminants began with Mycoplasma ovis (formerly Eperythrozoon ovis) and "Candidatus Mycoplasma haemovis" (HORNOK et al., 2012). At present, it is not clear whether these hemoplasmas are single species or separate 
strains/species remains, mainly because the complete genome sequence of $M$. ovis strain Michigan contains two copies of the $16 \mathrm{~S}$ rDNA genes, corresponding to the previously reported sequences for M. ovis and 'Ca. M. haemovis' (DESHUILLERS et al., 2014).

Animal infections with HM are characterized by asymptomatic to subtle chronic anemia, and occasionally by an overt life-threatening hemolytic anemia. (MESSICK, 2004; NEIMARK et al., 2004; HOELZLE, 2008). Mycoplasma ovis (formerly Eperythrozoon ovis) transmission by hematophagous ticks, such as Rhipicephalus bursa, has experimentally been demonstrated in Russia (NIKOL'SKIĬ \& SLIPCHENKO, 1969). Since $R$. bursa has never been found in the New World, it is still unknown which vector participates in the transmission of $M$. ovis in our geographic location.

Among the routes of transmission of diverse HM species, we can comment the involvement of other arthropods, such as fleas, Ctenocephalides felis, as a probable vector for $M$. haemofelis and "Candidatus M. haemominutum" (SHAW et al., 2004; WOODS et al., 2005; LAPPIN et al., 2006), or the louse Polyplax serrata, transmitting Mycoplasma coccoides to rats (BERKENKAMP \& WESCOTT, 1988). The canine tick Rhipicephalus sanguineus is the vector of Haemobartonella canis, currently known as Mycoplasma haemocanis (SENEVIRATNA et al., 1973). There are also evidences of vertical transmission in cattle (GIROTTO-SOARES et al., 2016). Considering that $M$. ovis has already been found infecting humans (SYKES et al., 2010; MAGGI et al., 2013), close and frequent human-animal contact, associated with the presence of arthropod vectors, may represent a risk for Public Health (MACHADO et al., 2017). There are reported cases of transmission through blood contact with animals that had invasive procedures such as castration, tail docking, mulesing, and even vaccination or ear tagging. (CAMPBELL et al., 1971; PHILBEY et al., 2006).

The FAMACHA ${ }^{\odot}$ system is a tool developed to identify anemic sheep and goats by evaluating the ocular mucosa when compared to a standard chart (VAN WYK \& BATH, 2002). According to the scale, the animal might need anthelmintic treatment. The FAMACHA ${ }^{\odot}$ score is directly related to anemia and indirectly with the packed cell volume (PCV). The scale ranges from 1 to 5 , with 1 being red mucous and the animal being considered non-anemic (PCV $>27)$, and 5 being white mucous, suggesting severe anemia $(\mathrm{PVC}<13)$ (VAN WYK \& BATH, 2002; KENYON \& JACKSON, 2012; MAIA et al., 2015). This scale serves as a tool in the selection of animals that are sensitive to anemias. The FAMACHA ${ }^{\odot}$ system is in line with the recommendations of the Integrated Parasite (pest) Management (IPM) (NARI, 2003; KAHN \& WOODGATE, 2012).
To date, there are no studies in Brazil describing $M$. ovis infections in sheep. The publications, so far, refer to $M$. ovis infections in captive and free-living deer (GRAZZIOTIN et al., 2011a; GRAZZIOTIN et al., 2011b), one $M$. ovis infection in goats (MACHADO et al., 2017), and there is a study in sheep from Argentina (AGUIRRE et al., 2009).

Although hemoplasmosis has been reported causing significant economic losses in sheep farming around the world, data for Brazilian herds remain scarce. In this context, the main aim of this study is to describe the first report of hemotrophic mycoplasmosis in sheep from Brazil. In addition, we evaluated factors associated with this infection in beef sheep on a farm in Rio Grande do Sul State in southern Brazil.

\section{Material and Methods}

\section{Study area and samples}

The samples for this study were obtained from a sheep beef production farm located in Cachoeira do Sul $\left(29^{\circ} 53^{\prime} 54^{\prime \prime} \mathrm{S}, 53^{\circ} 00^{\prime} 20^{\prime \prime} \mathrm{W}\right)$, state of Rio Grande do Sul, southern Brazil, in April 2016. All the sheep in the farm, 33 animals, were collected for whole blood samples in EDTA-K $\mathrm{K}_{2}$ by jugular venipuncture. These sheep are routinely collected for sanitary analysis and the samples were given for research proposes. After the collection, the EDTA- $\mathrm{K}_{2}$ tubes were refrigerated, transported to the laboratory, and immediately stored at $-20^{\circ} \mathrm{C}$ prior to DNA extraction and further processing and analysis. At the time of sampling, the animals had no obvious clinical signs compatible with hemoplasmosis. On the farm, the animals were kept in a pasture with a daily food supplementation; salt was offered ad libitum. Cattle and horses used the same grazing area. The flock was composed of mixed breed sheep, with a predominance of Texel breed.

Epidemiological data collected from the farm included addressing age, presence of ticks, and $\mathrm{FAMACHA}^{\odot}$ scoring, since it was not possible to evaluate the PCV from the samples. Sheep age was determined and later stratified into groups of $<1.5$ years and $>1.5$ years. Ticks were removed directly from the animals and kept in tubes with $70 \%$ ethanol for further classification according to morphological taxonomic keys (BARROS-BATTESTI, 2006). The results for the FAMACHA ${ }^{\odot}$ score were stratified for statistical purposes into groups of non-anemic (score $\leq 2)$ and anemic (score $>2$ ) animals (Table 1).

Table 1. Infection rate of hemoplasmas (Mycoplasma ovis) and result of the proportion test for the variable ticks, age group, Famacha ${ }^{\odot}$ score in sheep in South Brazil.

\begin{tabular}{|c|c|c|c|c|c|c|c|c|c|c|c|}
\hline \multirow{2}{*}{ Variables } & \multicolumn{2}{|c|}{ Age group } & \multicolumn{2}{|c|}{ Ticks } & \multicolumn{2}{|c|}{ Stratified famacha score } & \multicolumn{4}{|c|}{ Score famacha ${ }^{\circledR}$} & \multirow[b]{2}{*}{5} \\
\hline & $<1.5$ year & $\geq 1.5$ year & Yes & No & Non anemic* & Anemic $^{\#}$ & 1 & 2 & 3 & 4 & \\
\hline GPpcr** & 10 & 16 & 13 & 13 & 23 & 3 & 10 & 13 & 3 & 0 & 0 \\
\hline GNpcr $^{\# \#}$ & 4 & 3 & 2 & 5 & 6 & 1 & 4 & 2 & 0 & 1 & 0 \\
\hline total & 14 & 19 & 15 & 18 & 29 & 4 & 14 & 15 & 3 & 1 & 0 \\
\hline Infection rate $(\%)$ & 71.4 & 84.2 & 72.2 & 86.6 & 79.3 & 75.0 & 71.4 & 86.6 & 100 & 0 & 0 \\
\hline P value & \multicolumn{2}{|c|}{0.4221} & \multicolumn{2}{|c|}{0.4134} & \multicolumn{2}{|c|}{0.4221} & \multicolumn{4}{|c|}{0.620} & \\
\hline
\end{tabular}

${ }^{*} \leq 2$ not anemic; ${ }^{*}>2$ anemic; ${ }^{* *} \mathrm{GPpcr}$ group positive in PCR to $M$. ovis; ${ }^{\# *} \mathrm{GNpcr}$ group negative in PCR to $M$. ovis; ${ }^{\circledR}$ Score Famacha; 1 = red, non-anemic (>27 PCV); 2 = red-pink, non-anemic (23 to $27 \mathrm{PCV}) ; 3$ = pink, mildly-anemic (18 to $22 \mathrm{PCV}) ; 4$ = pink-white, anemic $(13$ to 17 PCV); 5 = white, severely anemic (<13 PCV). 


\section{DNA samples}

Total Genomic DNA from $500 \mu \mathrm{L}$ of blood was extracted using a standard phenol-chloroform protocol (SAMBROOK \& RUSSEL, 2006) and quantified in a NanoDrop Lite Spectrophotometer (Thermo Scientific ${ }^{\mathrm{TM}}$ ); subsequently, the samples were stored at $-20^{\circ} \mathrm{C}$ until PCR testing.

\section{PCR amplification}

All samples were tested by a conventional PCR protocol using the forward primer HBT F 5' ATACGGCCCATATTCCTACG 3 and the reverse primer HBT R 5' TGCTCCACCACTTGTTCA 3', targeting a 595- to 620-bp fragment of the hemotrophic mycoplasma $16 \mathrm{~S}$ rRNA gene, as previously described by Criado-Fornelio et al. (2003).

\section{Sequencing and phylogenetic analysis}

The PCR products were submitted to electrophoresis through a $1.5 \%$ agarose gel and examined by a UV transilluminator. Amplicons of the expected size of three positive samples were purified with the PureLink kit (Invitrogen ${ }^{\circledR}$ ) and sequenced in an automatic sequencer (Sanger) according to the manufacturer's protocol. Generated sequences were submitted to BLAST ${ }^{\circledR}$ analysis (ALTSCHUL et al., 1990) to determine the closest similarities in GenBank ${ }^{\circledR}$ Partial sequences of the 16S rRNA gene of hemotrophic mycoplasmas derived from sheep were aligned with corresponding 16S rRNA sequences of 20 Mycoplasma species retrieved from GenBank ${ }^{\circledR}$, using Clustal/W v.1.8.1 (THOMPSON et al., 1994). A maximum likelihood phylogenetic tree using the GTR + G + I substitution model was generated using the Mega 7 software (KUMAR et al., 2016) with 100 bootstrap replicates. The substitution model was selected using the Mega 7 software (KUMAR et al., 2016), according to the lowest Bayesian Information Criterion (BIC) score. Sequence NR 113659 of Mycoplasma pneumoniae, a non-hemotrophic mycoplasma, was used as outgroup. An identity matrix calculated with the BioEdit software used sequences of $M$. ovis deposited in GenBank ${ }^{\circledR}$ and the ones found in this study to evaluate the similarity (Table 2).

\section{Statistical Analysis}

The variables age group, tick presence, and FAMACHA ${ }^{\odot}$ score (considering anemic animals with a score greater than 2) were analyzed for the groups GPpcr (positive group in PCR) and GNpcr (negative group in PCR) by Fisher's exact test. Differences in the distribution of the scores obtained in the FAMACHA ${ }^{\odot}$ method for the GPpcr and GNpcr groups were analyzed through the Mann Whitney U Test of independent samples. The level of significance used as criteria value for rejection of the null hypothesis was $5 \%(\mathrm{p} \leq 0.05)$. Statistical analyses were conducted using IBM SPSS Statistics for Windows, version 22.0 (IBM Corp. Armonk, NY, 2013).

\section{Results}

Of the 33 animals, 26 (78.8\%) were positive to hemoplasmas by PCR amplification of the $16 \mathrm{~S}$ rRNA gene (Table 1 ). The $16 \mathrm{~S}$ rRNA gene sequences of three $M$. ovis-like isolates had a $100 \%$ identity to $M$. ovis in sheep (KU983741 and KU983740) taken from GenBank ${ }^{\circledR}$. Three isolates having 16S rRNA gene sequences were included in the phylogenetic tree (Figure 1). The DNA sequences generated in the present study have been deposited in GenBank $^{\circledR}$ under the accession numbers MH379798 (613 pb), MH379799 (616 pb), and MH379800 (613 pb). The phylogenetic tree (Figure 1) depicts the three sequences of $M$. ovis generated in this study forming a cluster with previous $M$. ovis $16 \mathrm{~S}$ rRNA sequences found at GenBank ${ }^{\circledR}$.

We collected 68 ticks from 15 out of 33 sheep (45.4\%). All ticks identified as $R$. (B.) microplus. Of these 15 animals, 13 were in the GPpcr (group positive PCR $M$. ovis). The characteristics of the ticks were as follows 11 males, 33 females, 19 nymphs, 1 larva; in the two remaining animals, part of GNpcr (group negative PCR M. ovis), 3 nymphs and 1 larva were collected (Table 1). Since the sheep in GPpcr were positive in blood when the ticks were removed, we did not perform PCR assays of the ectoparasites.

There were no statistical differences between the groups GPpcr and GNpcr in terms of the presence of ticks ( $p=0.4134)$, age group ( $\mathrm{p}=0.4221)$, qualitative results of the stratified FAMACHA $^{\odot}$ score groups: non-anemic (score $\left.\leq 2\right)$ and anemic $($ score $>2)(p=0.4221)$, and the distribution of the FAMACHA ${ }^{\circledR}$ score $(1$ to 5$)(\mathrm{p}=0.620)$ (Table 1$)$.

Table 2. Identity matrix of Mycoplasma ovis sequence of the present study (1,2 and 3) and isolates of Mycoplasma deposited in Genbank ${ }^{\circledR}$.

\begin{tabular}{lccccc}
\hline \multicolumn{1}{c}{ Sequences } & $\mathbf{1}$ & $\mathbf{2}$ & $\mathbf{3}$ & $\mathbf{4}$ & $\mathbf{5}$ \\
\hline 1. $[\mathrm{MH} 379798]$ Mycoplasma ovis 1 Sheep & ID & & & & \\
2. [MH379799] M. ovis 2 Sheep & 1 & ID & & & \\
3. [MH379800] M. ovis 3 Sheep & 1 & 1 & ID & & \\
4. [KU983740] M. ovis sheep & 0.998 & 0.998 & 0.998 & ID & ID \\
5. [KF313922] M. ovis Human & 0.998 & 0.998 & 0.998 & 1 & 0.985 \\
6. [HQ634377] Mycoplasma spp. Ozotoceros bezoarticus & 0.983 & 0.983 & 0.983 & 0.985 & ID \\
\hline
\end{tabular}




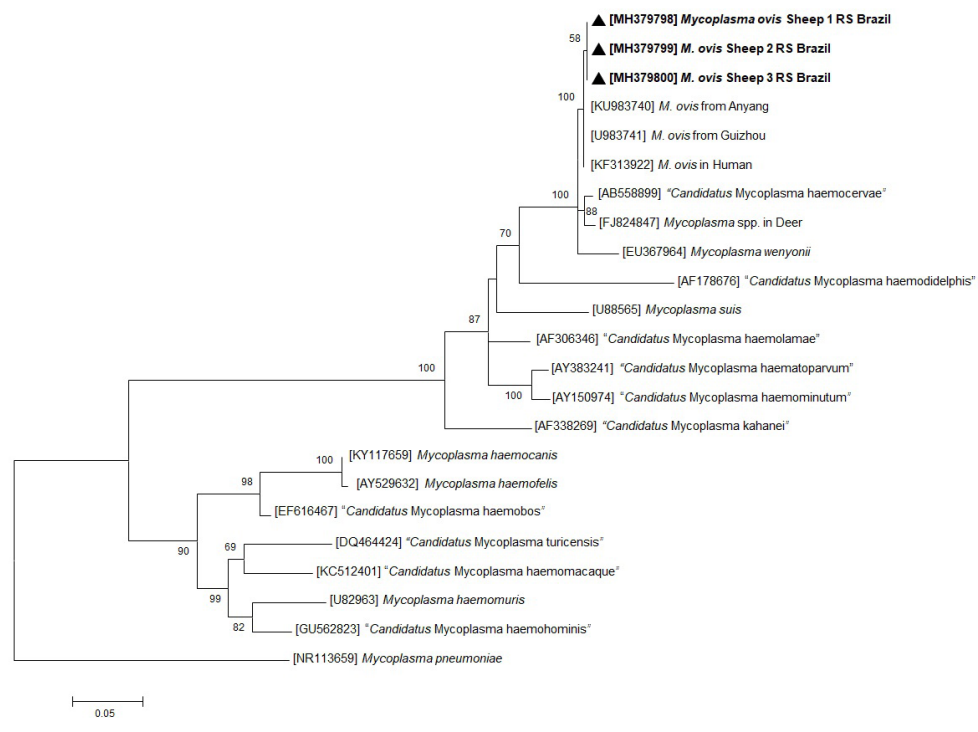

Figure 1. Maximum likelihood phylogenetic tree of $16 \mathrm{~S}$ rRNA partial sequences of Mycoplasma ovis and other mycoplasmas. Numbers on the nodes indicate bootstrap values from 100 replicates. Only bootstrap values $>50$ are shown. Numbers in brackets are GenBank ${ }^{\circledR}$ accession numbers. The $M$. ovis sequences generated in the present study are in bold, indicated by a black arrow head.

\section{Discussion}

This is the first molecular detection of $M$. ovis in sheep in Brazil and only the second report of $M$. ovis in sheep from Latin America (AGUIRRE et al., 2009). Considering that Haemonchus contortus is an important cause of anemia in sheep (due to the consumption of whole blood) and severely impacts ovine breeding, any agent that causes hemolysis, such as $M$. ovis, gains special importance. There are distinct pathogenic processes that both contribute to the development of anemia in animals; however, hemoplasmosis remains largely neglected in small ruminant in Latin America. Given this, it is crucial to report the occurrence of this pathogen in Brazil.

Studies with experimental M. ovis (mentioned as Eperythozoon ovis) infection in sheep have shown that the control group (no infection) had a mean of $10.35 \mathrm{~g} / \mathrm{dL} \mathrm{Hb}$, with a PCV of $30.50 \%$, while the infected group showed $6.45 \mathrm{~g} / \mathrm{dL} \mathrm{Hb}$, with an average PCV of $18.17 \%$. This suggests that $M$. ovis infection causes a large hematological alteration in sheep (DADDOW, 1979). Another study has evaluated the prevalence, diagnosis, and hematological changes that HM causes in sheep. Subclinical infection was associated with changes in mean corpuscular volume (MCV), mean corpuscular hemoglobin concentration (MCHC), red cell distribution width (RDW) and absolute monocyte count (HAMPEL et al., 2014). However, these changes were not evident in our study due to the evaluation method used, the FAMACHA ${ }^{\odot}$ score, which measures PVC indirectly (see Table 1). Therefore, although there was no significant association between of the stratified FAMACHA ${ }^{\odot}$ score groups: non-anemic (score $\leq 2)$ and anemic (score $>2)$ and the distribution of the FAMACHA ${ }^{\odot}$ score (1 to 5) (Table 1 ) and presence $M$. ovis infection hematological alterations can be present in the studied herd, but were not detected.

The occurrence of $M$. ovis observed in this study $(78.8 \%)$ was higher than that found for sheep in Hungary $(51.5 \%)$
(HORNOK et al., 2009), goats in China (41\%) (SONG et al., 2014), and goats in Brazil (39.30\%) (MACHADO et al., 2017). In Argentina, a study described an outbreak of mycoplasmosis resulting in sheep death. Necropsy showed signs of anemia, mild subcutaneous jaundice, marked hepatic jaundice, splenomegaly, friable kidneys, congestion and pulmonary edema. The sheep were positive in the PCR for M. ovis (AGUIRRE et al., 2009).

We could not relate the involvement of a vector in the studied population, and therefore, there might be other transmission routes. Given the lack of information about the vectors in Brazil, other routes of transmission may be involved, such as other vectors, or iatrogenic and vertical transmission.

We found no significant association between the presence of HM and tick infestation, as observed in previous studies (RJEIBI et al., 2015). In a study conducted in northeastern Brazil no association was found between tick infestation and $M$. ovis infection in goats. The authors discuss that the lack of association may be linked to the control of tick used in the property and also to local factors of the region studied (MACHADO et al., 2017). Many of sheep were infested with ticks, which is not common for wool-covered sheep. There is a probability that this infestation was influenced by the unusually warm weather, favoring tick activity and reproduction. In addition, the cattle from the same property received strategical treatment for tick infestation, using acaricides with significant residue; we therefore speculate that this might have favored the infestation of $R$. (B.) microplus in the sampled sheep. In Mexico, $R$. (B.) microplus has been found infected with $M$. ovis present in sick sheep (MARTÍNEZ-HERNÁNDEZ et al., 2018). In the Old World, $R$. bursa is a known vector for $M$. ovis (NIKOL'SKII \& SLIPCHENKO, 1969), and the lack of this species in the New World raises suspicion that $R$. (B.) microplus could be the vector, since it is the most common species infesting sheep in this locality and belongs to the same genus as the one from Russia. 
It should be noted that the sampled animals were apparently healthy, and there was no statistically significant difference in distribution of FAMACHA ${ }^{\odot}$ scores between GPpcr and GNpcr. This could be explained by the selection of resistant animals, eliminating from the herd those that presented signs of anemia, which has been practiced for more than 10 years on this property. Also, nutritional supplementation has a positive effect on the resistance of parasitized sheep (HAILE et al., 2004; LOUVANDINI et al., 2006; MELO et al., 2017).

The high occurrence of $M$. ovis in the studied sheep can be explained by the potential of hemotrophic mycoplasmas to spread easily among animals due to the variety of transmission routes previously described, such as ticks, fleas, mosquitoes, and lice (DADDOW, 1981; SENEVIRATNA et al., 1973; BERKENKAMP \& WESCOTT, 1988; SHAW et al., 2004; WOODS et al., 2005; LAPPIN et al., 2006; AKTAS \& OZUBEK, 2017). Contamination via surgical procedures, such as vaccination, injectable anti-parasitic treatment, ear tagging, castration, tail docking, and mulesing, increases the risk of bloodborne transmission (CAMPBELL et al., 1971; PHILBEY et al., 2006), Transplacental transmission also occurs, thus allowing a wide circulation of the pathogen not only in sheep, but also in other domestic and wild mammals, as already demonstrated in Brazil for free-living and captive deer (GRAZZIOTIN et al., 2011a; GRAZZIOTIN et al., 2011b). Transplacental transmission of "Candidatus Mycoplasma haemobos" between cows and their fetuses, both collected from an abattoir, has been reported in southern Brazil (GIROTTO-SOARES et al., 2016).

It is possible that hemoplasmas can act in synergy with other agents contributing to the worsening of infections and increasing lethality, especially in herds infected concomitantly with Haemonchus contortus. A synergic interaction between hemoplasmas and Anaplasma sp. was demonstrated in outbreaks that resulted in mortality of sheep (HORNOK et al., 2009; MARTÍNEZ-HERNÁNDEZ et al., 2018) and cattle (HORNOK et al., 2012). Hornok et al. (2009) have shown that $73 \%$ of the animals in their study had coinfections. Besides this synergic relation, hemotrophic mycoplasmas can cause severe anemia (GENOVA et al., 2011) and even death in cattle (GLADDEN et al., 2016) as an isolated agent. Close and frequent human-animal contact, associated with the presence of arthropod vectors, may represent a risk for Public Health (MACHADO et al., 2017), considering that $M$. ovis has already been found infecting humans associated with other pathogens (SYKES et al., 2010; MAGGI et al., 2013).

\section{Conclusions}

In the New World, further studies evaluating the pathogenicity and transmission of sheep hemoplasmas are important. Large-scale studies are necessary to verify the occurrence in other regions of Brazil. Phylogenetic analyses showed that all three sequences of $M$. ovis generated at the present study formed a cluster with previous $16 \mathrm{~S}$ rRNA of $M$. ovis sequences found at GenBank ${ }^{\circledR}$. Few data is available about $M$. ovis infections in Brazil, and the clinical and economic significance of hemoplasmas. The fact that we did not find statistical differences between groups GPpcr and GNpcr and the presence of ticks, age group, qualitative results of the $\mathrm{FAMACHA}^{\odot}$ score may not show the reality of other herds. We provide molecular evidence for the presence of hemotrophic mycoplasma in sheep, representing the first report of $M$. ovis in sheep in Brazil, with a high occurrence of this organism in sheep from a farm in the south of Brazil. For sheep farmers, this should be a warning sign, given that this pathogen is an important cause of anemia and economic losses, whether it is the only infectious agent or simultaneously occurs with other diseases. In this sense, it is relevant to add $M$. ovis as a differential diagnosis for hemolytic disorders in Brazilian sheep.

\section{Acknowledgements}

This study was supported by the Conselho Nacional de Desenvolvimento Científico e Tecnológico (CNPq), Coordenação de Aperfeiçoamento de Pessoal de Nível Superior - Brasil (CAPES). Finance code 001 . The authors are grateful for the assistance of Elba Marques Soares and Jeremias Becker Soares.

\section{References}

Aguirre DH, Thompson C, Neumann RD, Salatin AO, Gaido AB, Echaide ST. Brote de micoplasmosis clínica por Mycoplasma ovis en ovinos de Salta, Argentina. Diagnóstico clínico, microbiológico y molecular. Rev Argent Microbiol 2009; 41(4): 212-214. PMid:20085183.

Aktas M, Ozubek S. A molecular survey of small ruminant hemotropic mycoplasmosis in Turkey, including first laboratory confirmed clinical cases caused by Mycoplasma ovis. Vet Microbiol 2017; 208: 217-222. http://dx.doi.org/10.1016/j.vetmic.2017.08.011. PMid:28888641.

Altschul SF, Gish W, Miller W, Myers EW, Lipman DJ. Basic local alignment search tool. J Mol Biol 1990; 215(3): 403-410. http://dx.doi. org/10.1016/S0022-2836(05)80360-2. PMid:2231712.

Barros-Battesti DM, Arzua M, Bechara G. Carrapatos de importância médico veterinária da regiäo neotropical: um guia ilustrado para identificaçāo de espécies. São Paulo: Vox/ICTTD-3; 2006

Berkenkamp SD, Wescott RB. Arthropod transmission of Eperythrozoon coccoides in mice. Lab Anim Sci 1988; 38(4): 398-401. PMid:3184845.

Campbell RW, Sloan CA, Harbutt PR. Observations on mortality in lambs in Victoria associated with Eperythrozoon ovis. Aust Vet J 1971; 47(11): 538-541. http://dx.doi.org/10.1111/j.1751-0813.1971.tb02048.x. PMid:5171271

Criado-Fornelio A, Martinez-Marcos A, Buling-Saraña A, Barba-Carretero JC. Presence of Mycoplasma haemofelis, Mycoplasma haemominutum and piroplasmids in cats from southern Europe: a molecular study. Vet Microbiol 2003; 93(4): 307-317. http://dx.doi.org/10.1016/S03781135(03)00044-0. PMid:12713893.

Daddow KN. Eperythrozoon ovis - a cause of anaemia, reduced production and decreased exercise tolerance in sheep. Aust Vet J 1979; 55(9): 433-434. http://dx.doi.org/10.1111/j.1751-0813.1979.tb05600.x. PMid:543836.

Daddow KN. The duration of the carrier state of Eperythrozoon ovis infection in sheep. Aust Vet J 1981; 57(1): 49. http://dx.doi. org/10.1111/j.1751-0813.1981.tb07091.x.

Deshuillers PL, Santos AP, Nascimento NC, Hampel JA, Bergin IL, Dyson MC, et al. Complete genome sequence of Mycoplasma ovis strain Michigan, a hemoplasma of sheep with two distinct 16S rRNA 
genes. Genome Announc 2014; 2(1): 1-2. http://dx.doi.org/10.1128/ genomeA.01235-13. PMid:24482515.

Genova SG, Streeter RN, Velguth KE, Snider TA, Kocan KM, Simpson KM. Severe anemia associated with Mycoplasma wenyonii infection in a mature cow. Can Vet J 2011; 52(9): 1018-1021. PMid:22379205.

Girotto A, Zangirólamo AF, Bogado AL, Souza AS, Silva GC, Garcia JL, et al. Molecular detection and occurrence of "Candidatus Mycoplasma haemobos" in dairy cattle of Southern Brazil. Rev Bras Parasitol Vet 2012; 21(3): 342-344. http://dx.doi.org/10.1590/S1984-29612012000300034. PMid:23070456.

Girotto-Soares A, Soares JF, Bogado ALG, Macedo CAB, Sandeski LM, Garcia JL, et al. 'Candidatus Mycoplasma haemobos': Transplacental transmission in dairy cows (Bos taurus). Vet Microbiol 2016; 195: 22-24.

Gladden N, Haining H, Henderson L, Marchesi F, Graham L, McDonald $\mathrm{M}$, et al. A case report of Mycoplasma wenyonii associated immune-mediated haemolytic anaemia in a dairy cow. Irish Vet J 2016; 69:1. https://doi. org/10.1186/s13620-016-0061-x

Grazziotin AL, Duarte JM, Szabó MP, Santos AP, Guimarães AM, Mohamed A, et al. Prevalence and molecular characterization of Mycoplasma ovis in selected free-ranging Brazilian deer populations. J Wildl Dis 2011a; 47(4): 1005-1011. http://dx.doi.org/10.7589/0090-3558-47.4.1005. PMid:22102675.

Grazziotin AL, Santos AP, Guimaraes AM, Mohamed A, Cubas ZS, Oliveira MJ, et al. Mycoplasma ovis in captive cervids: prevalence, molecular characterization and phylogeny. Vet Microbiol 2011b; 152(3-4): 415-419. http://dx.doi.org/10.1016/j.vetmic.2011.05.001. PMid:21640523.

Groebel K, Hoelzle K, Wittenbrink MM, Ziegler U, Hoelzle LE. Mycoplasma suis invades porcine erythrocytes. Infect Immun 2009; 77(2): 576-584. http://dx.doi.org/10.1128/IAI.00773-08. PMid:19015255.

Haile A, Anindo DO, Tembely S, Mukasa-Mugerwa E, Tibbo M, Yami A, et al. Effects of dietary protein supplementation and infection with gastrointestinal nematode parasites on some nutritional and metabolic parameters in Ethiopian Menz and Horro sheep. Livest Prod Sci 2004; 91(1-2): 183-195. http://dx.doi.org/10.1016/j.livprodsci.2004.08.003.

Hampel JA, Spath SN, Bergin IL, Lim A, Bolin SR, Dyson MC. Prevalence and diagnosis of hemotrophic mycoplasma infection in research sheep and its effects on hematology variables and erythrocyte membrane fragility. Comp Med 2014; 64(6): 478-485. PMid:25527029.

Hoelzle LE. Haemotrophic mycoplasmas: recent advances in Mycoplasma suis. Vet Microbiol2008; 130(3-4): 215-226. http://dx.doi.org/10.1016/j. vetmic.2007.12.023. PMid:18358641.

Hornok S, Hajtós I, Meli ML, Farkas I, Gönczi E, Meili T, et al. First molecular identification of Mycoplasma ovis and 'Candidatus M. haemoovis' from goat, with lack of haemoplasma PCR-positivity in lice. Acta Vet Hung 2012; 60(3): 355-360. http://dx.doi.org/10.1556/AVet.2012.030. PMid:22903080.

Hornok S, Meli ML, Erdos A, Hajtós I, Lutz H, Hofmann-Lehmann R. Molecular characterization of two different strains of haemotropic mycoplasmas from a sheep flock with fatal haemolytic anaemia and concomitant Anaplasma ovis infection. Vet Microbiol 2009; 136(3-4): 372377. http://dx.doi.org/10.1016/j.vetmic.2008.10.031. PMid:19091491.

Kahn LP, Woodgate RG. Integrated parasite management: products for adoption by the Australian sheep industry. Vet Parasitol 2012; 186(1-2): 58-64. http://dx.doi.org/10.1016/j.vetpar.2011.11.046. PMid:22154258.

Kenyon F, Jackson F. Targeted flock/herd and individual ruminant treatment approaches. Vet Parasitol 2012; 186(1-2): 10-17. http://dx.doi. org/10.1016/j.vetpar.2011.11.041. PMid:22188982.
Kumar S, Stecher G, Tamura K. MEGA7: Molecular Evolutionary Genetics Analysis version 7.0 for bigger datasets. Mol Biol Evol 2016; 33(7): 18701874. http://dx.doi.org/10.1093/molbev/msw054. PMid:27004904.

Lappin MR, Griffin B, Brunt J, Riley A, Burney D, Hawley J, et al. Prevalence of Bartonella species, haemoplasma species, Ehrlichia species, Anaplasma phagocytophilum, and Neorickettsia risticii DNA in the blood of cats and their fleas in the United States. J Feline Med Surg 2006; 8(2): 85-90. http://dx.doi.org/10.1016/j.jfms.2005.08.003. PMid:16290092.

Louvandini H, Veloso CFM, Paludo GR, Dell'Porto A, Gennari SM, McManus CM. Influence of protein supplementation on the resistance and resilience on young hair sheep naturally infected with gastrointestinal nematodes during rainy and dry seasons. Vet Parasitol 2006; 137(1-2): 103111. http://dx.doi.org/10.1016/j.vetpar.2006.01.004. PMid:16495016.

Machado CAL, Vidotto O, Conrado FO, Santos NJR, Valente JDM, Barbosa IC, et al. Mycoplasma ovis infection in goat farms from northeastern Brazil. Comp Immunol Microbiol Infect Dis 2017; 55: 1-5. http://dx.doi. org/10.1016/j.cimid.2017.08.004. PMid:29127988.

Maggi RG, Compton SM, Trull CL, Mascarelli PE, Mozayeni BR, Breitschwerdt EB. Infection with hemotropic Mycoplasma species in patients with or without extensive arthropod or animal contact. $J$ Clin Microbiol 2013; 51(10): 3237-3241. http://dx.doi.org/10.1128/ JCM.01125-13. PMid:23863574.

Maia D, Rosalinski-Moraes F, Torres-Acosta JF, Cintra MC, Sotomaior CS. FAMACHA@ system assessment by previously trained sheep and goat farmers in Brazil. Vet Parasitol 2015; 209(3-4): 202-209. http:// dx.doi.org/10.1016/j.vetpar.2015.02.033. PMid:25805324.

Martínez-Hernández JM, Ballados-González GG, Fernández-Bandala D, Martínez-Soto S, Velázquez-Osorio V, Martínez-Rodríguez PB, et al. Molecular detection of Mycoplasma ovis in an outbreak of hemolytic anemia in sheep from Veracruz, Mexico. Trop Anim Health Prod 2018; 51(1): 243248. http://dx.doi.org/10.1007/s11250-018-1648-x. PMid:29934796.

Melo GKA, Ítavo CCBF, Monteiro KLS, Silva JA, Silva PCG, Ítavo LCV, et al. Effect of creep-fed supplement on the susceptibility of pasture-grazed suckling lambs to gastrointestinal helminths. Vet Parasitol 2017; 239: 26-30. http://dx.doi.org/10.1016/j.vetpar.2017.04.017. PMid:28495192.

Messick JB. Hemotrophic mycoplasmas (hemoplasmas): a review and new insight into pathogenic potential. Vet Clin Pathol 2004; 33(1): 2-13. http://dx.doi.org/10.1111/j.1939-165X.2004.tb00342.x. PMid:15048620.

Nari A. Resistencia a los Antiparasitarios. Estado actual con énfasis en América Latina. FAO Producción y Sanidad Animal 2003; 157: 1-60.

Neimark H, Hoff B, Ganter M. Mycoplasma ovis comb. nov. (formerly Eperythrozoon ovis), an epierythrocytic agent of haemolytic anaemia in sheep and goats. Int J Syst Evol Microbiol 2004; 54(Pt 2): 365-371. http:// dx.doi.org/10.1099/ijs.0.02858-0. PMid:15023944.

Nikol'skiĭ SN, Slipchenko SN. Experiments in the transmission of Eperythrozoon ovis by the ticks $H$. plumbeum and Rh. bursa. Veterinariia 1969; 5: 46. PMid:5393434.

Philbey AW, Barron RC, Gounden A. Chronic eperythrozoonosis in and adult ewe. Vet Rec 2006; 158(19): 662-664. http://dx.doi.org/10.1136/ vr.158.19.662. PMid:16699137.

Rjeibi MR, Darghouth MA, Omri H, Souidi K, Rekik M, Gharbi M. First molecular isolation of Mycoplasma ovis from small ruminants in North Africa. Onderstepoort J Vet Res 2015; 82(1): e1-e6. http://dx.doi. org/10.4102/ojvr.v82i1.912. PMid:26244681. 
Sambrook J, Russel DW. Molecular Cloning: a laboratory manual. 3rd ed. USA: Cold Spring Harbor; 2006.

Seneviratna P, Weerasinghe N, Ariyadasa S. Transmission of Haemobartonella canis by the dog tick, Rhipicephalus sanguineus. Res Vet Sci 1973; 14(1): 112114. http://dx.doi.org/10.1016/S0034-5288(18)33950-X. PMid:4736045.

Shaw SE, Kenny MJ, Tasker S, Birtles RJ. Pathogen carriage by the cat flea Ctenocephalides felis (Bouché) in the United Kingdom. Vet Microbiol 2004; 102(3-4): 183-188. http://dx.doi.org/10.1016/j.vetmic.2004.06.013. PMid:15327793.

Song W, Song Q, He L, Zhou Y, Zhao J. The establishment and application of a semi-nested PCR assay for the detection of Mycoplasma ovis. Small Rumin Res 2014; 119(1-3): 176-181. http://dx.doi.org/10.1016/j. smallrumres.2014.03.001.

Sykes JE, Lindsay LL, Maggi RG, Breitschwerdt EB. Human coinfection with Bartonella henselae and two hemotropic mycoplasma variants resembling Mycoplasma ovis. J Clin Microbiol 2010; 48(10): 3782-3785. http://dx.doi.org/10.1128/JCM.01029-10. PMid:20702675.
Thompson JD, Higgins DG, Gibson TJ. CLUSTAL W: improving the sensitivity of progressive multiple sequence alignment through sequence weighting, position-specific gap penalties and weight matrix choice. Nucleic Acids Res 1994; 22(22): 4673-4680. http://dx.doi.org/10.1093/ nar/22.22.4673. PMid:7984417.

van Wyk JA, Bath GF. The FAMACHA system for managing haemonchosis in sheep and goats by clinically identifying individual animals for treatment. Vet Res 2002; 33(5): 509-529. http://dx.doi.org/10.1051/ vetres:2002036. PMid:12387487.

Woods JE, Brewer MM, Hawley JR, Wisnewski N, Lappin MR. Evaluation of experimental transmission of Candidatus Mycoplasma haemominutum and Mycoplasma haemofelis by Ctenocephalides felis to cats. Am J Vet Res 2005; 66(6): 1008-1012. http://dx.doi.org/10.2460/ ajvr.2005.66.1008. PMid:16008224.

Zhou RQ, Nie K, Huang HC, Hu SJ, Zhou ZY, Luo HL. Phylogenetic analysis of Mycoplasma suis isolates based on 16S rRNA gene sequence in China. Vet Res Commun 2009; 33(8): 855-863. http://dx.doi.org/10.1007/ s11259-009-9234-3. PMid:19590972. 